$[ノ-ト]$

\title{
白金族元素担持炭素棒発熱体を用いた 熱拡散反応管によるメタン脱水素カップリング反応
}

\author{
鈴木 信市 $^{\dagger 1)}$ ，田村 淳 $^{\dagger 2)}$ ，小原 秀一 ${ }^{+2)}$ ，尾上 薫 ${ }^{\dagger 2)}$ ，山口 達明 ${ }^{\dagger 2) *}$ \\ +1) 石油公団石油開発技術センター, 261 千葉市美浜区浜田 1-2-2 \\ +2) 千葉工業大学工業化学科, 275 千葉県習志野市津田沼 2-17-1
}

(平成 7 年 5 月 19 日受理)

\begin{abstract}
生成物の逐次反応を抑制しうることで知られる熱拡散反応管において，炭素棒発熱体の表面修飾の容易性に着眼し て, 水素の関与する反応に対して促進効果を持つことで知られる白金族元素（白金，ルテニウム， ロジゥム）を炭素 棒発熱体に担持して反応に用いることにより, メタン脱水素カップリング反応に対する効果を検討した。実験は, 原 料メタンを下降流で $1.64 \mathrm{mmol} \cdot \mathrm{min}^{-1}$ の流速で Clusius-Dickel 型の熱拡散反応管（内管: 内径 $14.5 \mathrm{~mm}$, 長さ 300 $\mathrm{mm}$, 外管: 内径 $32.0 \mathrm{~mm}$, 長さ $250 \mathrm{~mm}$ ）に供給し, 発熱体温度を $800 \sim 1300 \mathrm{~K}$ の炭素質および油状生成物が少な い領域に設定して行った。白金族元素担持炭素棒を用いた場合は無担持のものに比べて, 脱水素カップリング反応速 度が促進されるとともに，気体状炭化水素収率が向上することが認められた。これは，発熱体の担持金属によるメ夕 ン脱水素反応の反応促進効果と熱拡散反応管による初期生成物である気体状生成物の反応系からの分離効果が複合さ れた結果であると考えられる。
\end{abstract}

\section{1. 緒言}

近年，メタンをエチレンなどの気体状炭化水素に転換する方 法として，酸化カップリング反応とともに，メタンを高温熱分 解することにより気体状炭化水素に転換する脱水素カップリン グ反応が検討されてきている。ところが，高温熱分解反応にお いては，メタン転化率を向上させようとすると，第一生成物の 気体状炭化水素がさらに脱水素反応を受けて油状物や炭素質と なり，気体状炭化水素の選択率が低下するという問題を生ず る1)。これを解決するために, 反応生成物を素早く反応系から 取り出してクェンチすることにより，メタン転化率を低下させ ずに気体状炭化水素の選択率を維持向上させようとする試みが なされてきた2)。

著者らは,このような試みの一つとして, 反応管内に温度こ う配を付した熱拡散反応管を用いる方法を検討している。その 結果, 温度こう配を有する系では, 反応と熱拡散効果および対 流効果による生成物分離とを同時に行うことにより，反応生成 物の過㮃な脱水素反応を抑制できること，さらに発熱体近傍へ の水素濃縮作用により，気体状炭化水素の選択率向上に必要な 水素希釈効果を引き起こすことを明らかにした ${ }^{3)}$ 。また，同反 応管の発熱体として従来用いられてきたタングステン線におけ る表面劣化や反応活性の低さの問題に関しては，炭素棒を用い れば劣化を起こさずに繰り返し使用が可能であり，また反応活 性を向上させうる表面修飾が可能であることを見い出しだ)。

本論文は, このような炭素棒発熱体の特徵に着眼して, 熱拡 散反応管を用いた脱水素カップリング反応の反応性を向上させ るために，水素の関与する反応に促進効果をもつ物質として知 られている ${ }^{5}$ 白金族元素を炭素棒発熱体に担持して反応を行っ

*連絡先
た結果を報告する。

\section{2. 実験方法}

\section{1. 白金族元秦担持炭秦棒の調製}

次のような方法で，白金，ルテニウム，ロジウムの白金族元 素担持炭素棒を調製した。

グラファイト，カーボンブラックを原料とした炭素棒（第一 カーボン (株) 製: $3.0 \mathrm{~mm} \phi$, 発熱体有効長さ $180 \mathrm{~mm}$ ) を担体と して, $0.5 \mathrm{~N}-\mathrm{HCl}$ 水溶液に 48 時間浸漬させた後, それぞれ $\mathrm{H}_{2} \mathrm{PtCl}_{6} \cdot 6 \mathrm{H}_{2} \mathrm{O}, \mathrm{RuCl}_{3} \cdot 8 \mathrm{H}_{2} \mathrm{O}, \mathrm{RhCl}_{3} \cdot 3 \mathrm{H}_{2} \mathrm{O}$ を用いて調製し た $32 \sim 43 \mathrm{mM}$ の水溶液に浸漬し，液を乾固させ白金族元素を 担持した。浸漬, 乾固は $30 \mathrm{~mm} \times 200 \mathrm{~mm} \times 30 \mathrm{~mm}$ の箱型ガラ 又製容器内で行った。浸漬後の還元は $1073 \mathrm{~K} て ゙ 2$ 時間, 水素 雲囲気下で行った。

使用前後の炭素棒の物性に関しては，担持した炭素棒の金属 担持率 $W t$ は重量法で, 金属結晶子径 $R c$ は $\mathrm{X}$ 線による (111) 面の半值幅法で, 発熱体比表面積 $S g$ は BET 法による窒素吸 着量から各々測定した。

\section{2. メタンの脱水秦カップリング反応}

上記により調製した炭素棒をFig. 1 に示す Clusius-Dickel 型熱拡散反応管 (内管: 内径 $14.5 \mathrm{~mm}$, 長さ $300 \mathrm{~mm}$, 外管: 内径 $32.0 \mathrm{~mm}$, 長さ $250 \mathrm{~mm}$ ) の発熱体として使用し, メタン の反応活性，生成物の選択性を比較検討した。原料ガスとして は，天然ガスやその他工業原料のメタンにしばしば $\mathrm{CO}_{2}$ が含 有されていることから, $\mathrm{CO}_{2}$ を $0.71 \%$ 含む市販の高濃度メ夕 ンを使用した。定常活性は原料ガスを流量 $1.64 \mathrm{mmol} \cdot \mathrm{min}^{-1}$ の下降流で供給後 8 時間で得られることを確認した。炭化水 素, 無機ガスなどの生成物分析は FID, TCD の計 3 台のガス クロマトグラフィーで行った。放射温度計により測定した発熱 


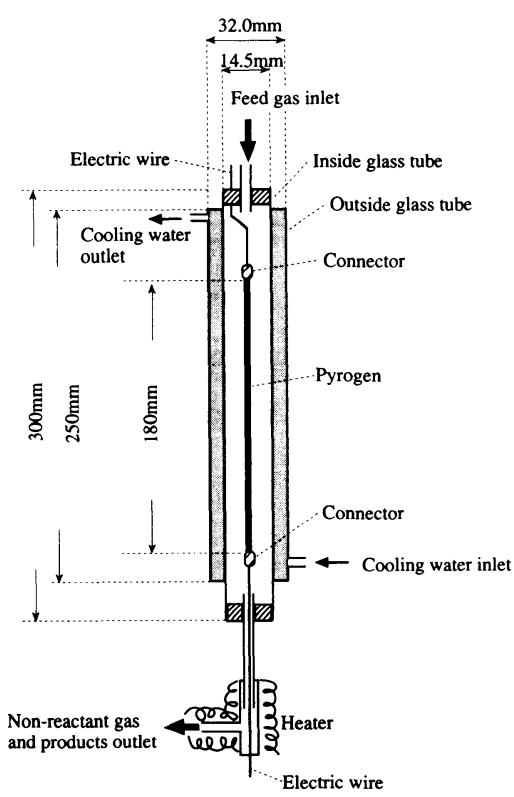

Fig. 1 Clusius-Dickel Type Thermal Diffusion Reactor

体表面の 5 点の平均温度を反応温度とし, 反応温度を内管壁 （熱電対で測定した平均温度は $308 \mathrm{~K}$ ) および発熱体表面に油 状物の付着, 炭素質の析出が生じない 800 1300 K の領域に 設定して実験を行った。

\section{3. 実験結果および考察}

\section{1. 宣金属担持岸菜棒の反応前後の物性比較}

担持または無担持炭素棒を用いた場合の活性の経時変化を測 定した結果, 反応開始 8 時間後に定常活性が得られ, 48時間 後も活性の低下は認められなかった。Fig. 2 に 8 時間反応に 供した白金担持炭素棒の白金結晶子径および比表面積の反応温 度依存性を示す。図中に示した白金結晶子径，比表面積は 48 時間使用後もほほ同一の值を示すことを確認した。白金の結晶 子径と BET 比表面積が比例して増大する理由は, 発熱体比表 面積の増加割合が結晶子径の増大による金属比表面積の減少割 合を上回ることによると考えられる。発熱体比表面積が増加す る要因としては, 金属担持後の水素還元および定常活性に達す るまでの反応過程で炭素棒表面に多孔化が生じ, 反応温度の上 昇に伴いこの多孔化が促進されたためと考えられる。ルテニウ ム, ロジゥムを担持した場合も金属結晶子径, 比表面積ともに $1000 \mathrm{~K}$ 付近で増大し, $1200 \mathrm{~K}$ 以上の高温領域では $900 \mathrm{~K}$ 以 下の低温領域に比べ比表面積は約 2 倍大きい結果が得られた。 Table 1 に $1273 \mathrm{~K}$ で 8 時間反応に供した白金族元素担持炭素 棒の金属結晶子径と比表面積の比較を示す。これより, 金属結 晶子径は発熱体表面積当たりの貴金属担持モル数 $M s$ と正の相 関を示すが，比表面積はMs が大きいロジウム担持炭素棒の方 が白金担持炭素棒より少ない結果が得られた。

\section{2. 担持金属による反応生成物の量い}

各炭素棒発熱体の反応温度 $T s[\mathrm{~K}]$ とメタンの転化率 $X[\%]$ の関係を Fig. 3 に示す。白金族元素を炭素棒発熱体に担持す

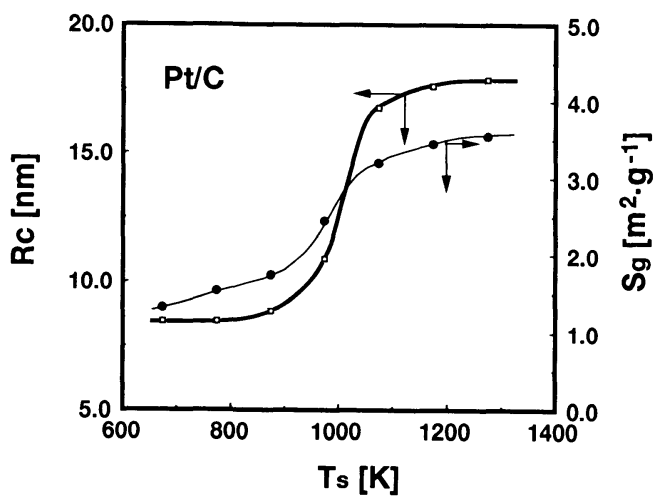

Reaction time: $8 \mathrm{~h}, \mathrm{CH}_{4}$ feed rate: $1.64 \mathrm{mmol} \cdot \mathrm{min}^{-1}$, $R c$ : XRD measurement, $S g$ : BET method.

Fig. 2 Dependence of Temperature of Reaction on the Change of Pt Crystallite Size and Specific Surface Area of Pyrogen

Table 1 Comparison of Physical Properties of Each Pyrogen (1273 K)

\begin{tabular}{cccccc}
\hline Pyrogen & Preparation & $\begin{array}{c}W t \\
{[\%]}\end{array}$ & $\begin{array}{c}M s \\
{\left[\mu \mathrm{mol}-\text { metal } / \mathrm{m}^{2}\right]}\end{array}$ & $\begin{array}{c}R c \\
{[\mathrm{~nm}]}\end{array}$ & $\begin{array}{c}S g \\
{\left[\mathrm{~m}^{2} / \mathrm{g}\right]}\end{array}$ \\
\hline $\mathrm{C}$ & $\mathrm{HCl}-\mathrm{H}_{2}$ & - & - & - & 1.61 \\
$\mathrm{Pt} / \mathrm{C}$ & $\mathrm{HCl}-\mathrm{Pt}-\mathrm{H}_{2}$ & 1.5 & 21.7 & 17.8 & 3.55 \\
$\mathrm{Ru} / \mathrm{C}$ & $\mathrm{HCl}-\mathrm{Ru}-\mathrm{H}_{2}$ & 2.2 & 54.2 & 31.9 & 4.02 \\
$\mathrm{Rh} / \mathrm{C}$ & $\mathrm{HCl}-\mathrm{Rh}-\mathrm{H}_{2}$ & 0.8 & 28.1 & 25.3 & 2.76 \\
\hline
\end{tabular}

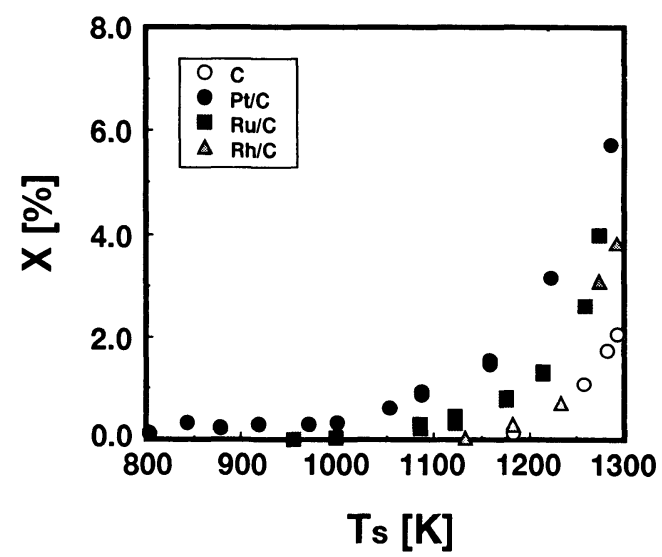

$\mathrm{CH}_{4}$ feed rate: $1.64 \mathrm{mmol} \cdot \mathrm{min}{ }^{1}$, pyrogen surface area : C $1.61 \mathrm{~m}^{2} \cdot \mathrm{g}^{-1}, \mathrm{Pt} / \mathrm{C} \quad 3.55 \mathrm{~m}^{2} \cdot \mathrm{g}^{-1}, \mathrm{Ru} / \mathrm{C} \quad 4.02 \mathrm{~m}^{2} \cdot \mathrm{g}^{-1}$, $\mathrm{Rh} / \mathrm{C} 2.76 \mathrm{~m}^{2} \cdot \mathrm{g}^{-1}$.

Fig. 3 Effect of Temperature of Reaction on Conversion of Methane

ると,メタン転化率が上昇するとともに反応開始温度が低下し た。各金属担持炭素棒発熱体の反応温度に対する生成物の選択 率の関係を Figs. 4a４cに示す。本実験の温度範囲では油状 物・炭素は観察されず, 反応前後の反応管および発熱体の重量 変化は認められなかった。選択率に示されている一酸化炭素 


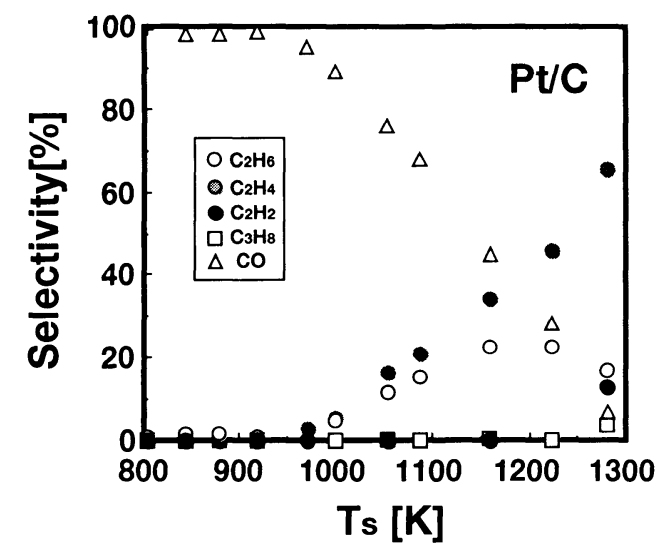

Fig. 4a Effect of Temperature of Reaction on Selectivities $(\mathrm{Pt} / \mathrm{C})$

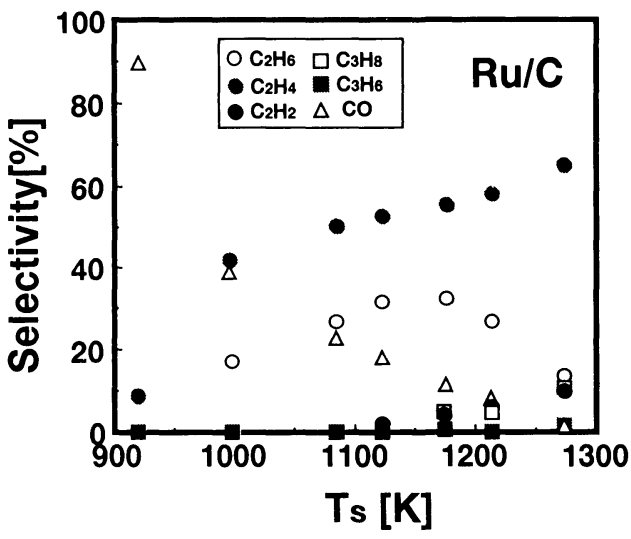

Fig. 4b Effect of Temperature of Reaction on Selectivities $(\mathrm{Ru} / \mathrm{C})$

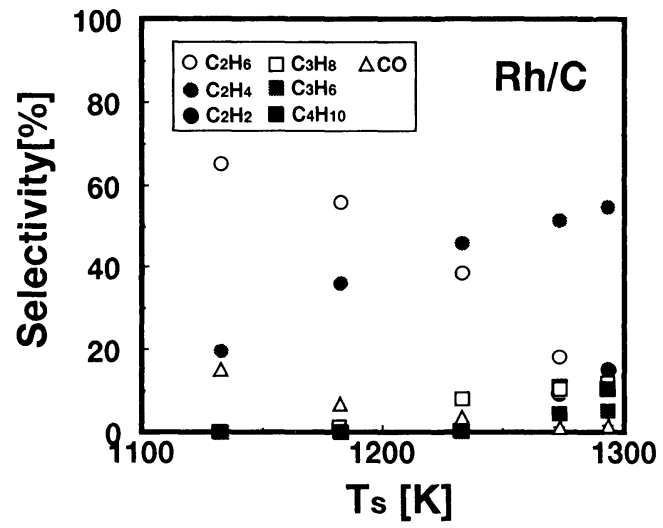

Fig. 4c Effect of Temperature of Reaction on Selectivities $(\mathrm{Rh} / \mathrm{C})$

は，原料ガス中に含まれる二酸化炭素によるメタンの改質反応 $\left(\mathrm{CH}_{4}+\mathrm{CH}_{2} \rightarrow 2 \mathrm{CO}+2 \mathrm{H}_{2}\right)$ で生じたものとして算出した。こ れより，二酸化炭素共存下ではメタンの脱水素カップリング反 応と二酸化炭素による改質反応が並発的に進行し, 白金担持の

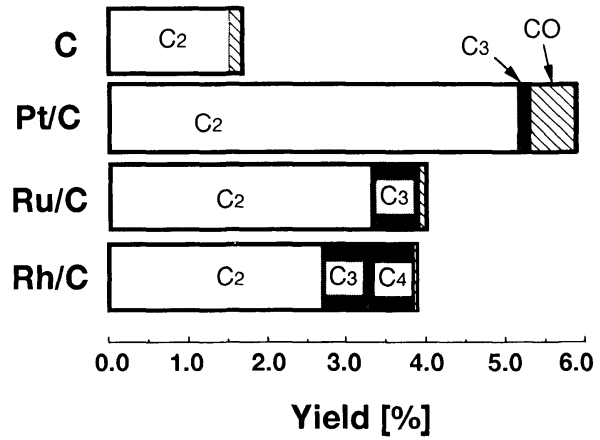

$\mathrm{CH}_{4}$ feed rate: $1.64 \mathrm{mmol} \cdot \mathrm{min}^{-1}$, pyrogen surface area C $1.61 \mathrm{~m}^{2} \cdot \mathrm{g}^{-1}, \mathrm{Pt} / \mathrm{C} 3.55 \mathrm{~m}^{2} \cdot \mathrm{g}^{-1}, \mathrm{Ru} / \mathrm{C} 4.02 \mathrm{~m}^{2} \cdot \mathrm{g}^{-1}$, $\mathrm{Rh} / \mathrm{C} 2.76 \mathrm{~m}^{2} \cdot \mathrm{g}^{-1}$.

Fig. 5 Product Yields (1273 K)

炭素棒を使用した場合は低温領域ほど前者に比べ後者の活性が 高いことが分かる。 $\mathrm{C}_{2}$ 炭化水素のみの選択率を比較すれば, 担持金属の違いによらず反応温度の増加とともにエタンが隇少 し，エチレン，ついでアセチレンが増加していく傾向にあり， これは温度上昇に伴い逐次的脱水素反応が進行したためと考え られる。発熱体温度 $1273 \mathrm{~K}$ での各炭素棒を用いた場合の転化 率と収率を Fig. 5 に示す。図では転換した原料ガスと気体状 生成物の炭素収支は $98 \%$ 以上が得られており，炭化水素以外 の成分のほとんどは一酸化炭素である。これより，1273 K 付 近の高温領域では，ルテニウム，ロジウム担持の場合は無担持 や白金担持の炭素棒に比較して, $\mathrm{C}_{3}$ 炭化水素の選択率が高く, さらにロジウム担持の場合のみ $\mathrm{C}_{4}$ 炭化水素が生成することが 特徴として挙げられる。

\section{3. 担持金属の反応促進効果}

白金族元素を担持した炭素棒を用いると，無担持の炭素棒を 用いた場合に比べて，同一温度でのメタン脱水素カップリング 反応および二酸化炭素による改質反応の活性が向上することが 認められた。そこで，各担持金属の脱水素カップリング反応に 対する促進効果を検討するために，発熱体表面積当たりの気体 状炭化水素へのメタンの転換速度 $r_{\mathrm{s}}$ の温度依存性を比較した ものが Fig. 6 である。白金およびルテニウム担持炭素棒にお ける $r_{\mathrm{s}}$ はほほ等しく，ロジウム担持炭素棒における $r_{\mathrm{s}}$ はそれ

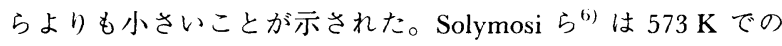
シリカに担持した白金, ルテニウム, ロジウム金属等のメタン 熱分解反応のメタン分解速度および $\mathrm{C}_{2}$ 炭化水素生成速度の促 進効果を検討し，メタン分解速度は大きい順からルテニウム， ロジウム, 白金, $\mathrm{C}_{2}$ 炭化水素生成速度は白金, ルテニウム, ロジウムであることを報告しているが, 本実験により $800 \sim 1300 \mathrm{~K}$ の温度範井においては, 気体状炭化水素生成速度 に対する炭素棒に担持した金属の脱水素カップリング反応促進 効果は, 白金, ルテニウムが大きく，ロジウムはこれに次ぐこ とが示された。

以上のように，炭素棒発熱体に白金族元素を担持して熱拡散 反応管によりメタンの脱水素カップリング反応を行うと，気体 状炭化水素の反応速度が促進されると同時に油状物抢よび炭素 生成が抑制され，気体状炭化水素収率が向上することが示され 


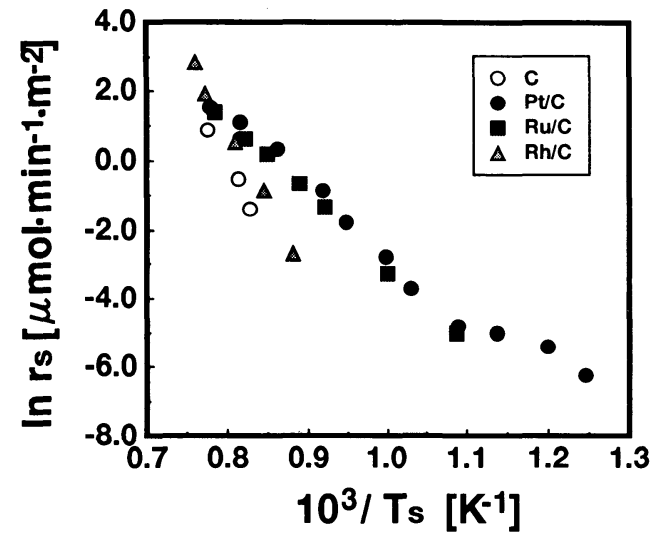

$\mathrm{CH}_{4}$ feed rate: $1.64 \mathrm{mmol} \cdot \mathrm{min}^{-1}$, pyrogen surface area: $\mathrm{C}$ $1.61 \mathrm{~m}^{2} \cdot \mathrm{g}^{-1}, \mathrm{Pt} / \mathrm{C} 3.55 \mathrm{~m}^{2} \cdot \mathrm{g}^{-1}, \mathrm{Ru} / \mathrm{C} 4.02 \mathrm{~m}^{2} \cdot \mathrm{g}^{-1}, \mathrm{Rh} / \mathrm{C}$ $2.76 \mathrm{~m}^{2} \cdot \mathrm{g}^{-1}$.

Fig. 6 Dependence on Temperature of Reaction on Dehydrogenative Coupling Rate of Methane per Surface Area of Pyrogen

た。これは，担持金属が逐次的なメタン脱水素反応を促進させ るとともに，熱拡散反応管による分離効果 ${ }^{3)}$ が生成する気体状 炭化水素を反応系外にクェンチすることにより過剩な脱水素反 応を抑制したことによると考えられる。

$\mathrm{Yu} ら^{7)}$ は，1273 K 以上に加熱した白金ワイヤーを設置し た反応管を用いてメタン熱分解反応の検討を行い，白金は脱水 素カップリング反応に対する促進効果があると報告している が，Yuらが用いた反応管も温度こう配を有すると考えられる ことから, $800 \mathrm{~K}$ 以上の高温領域において, 触媒を用いて脱水 素カップリング反応を促進し炭素生成を抑制するためには，熱 拡散反応管を用いる方法が有効であることが示唆される。

\section{4. 結}

白金,ルテニウム，ロジウムの白金族元素を担持した炭素棒 発熱体を用いた熱拡散反応管により，800～ $1300 \mathrm{~K}$ の発熱体温
度でメタンの脱水素カップリング反応を行った結果, 以下の知 見が得られた。

1）白金，ルテニウム，ロジウムの炭素棒発熱体への担持は, 無担持のものに比べて脱水素カップリング反応速度を促進する とともに気体状炭化水素収率を向上させた。

2）白金族元素担持炭素棒を用いた場合の脱水素カップリング 反応速度の促進効果を担持金属間で比較すると, 白金, ルテニ ウムが大きく，ロジウムがこれらに次いでいる。

3）発熱体温度 $1273 \mathrm{~K} に$ において各炭素棒を用いた場合の反応 生成物を比較すると，ルテニウム，ロジウム担持炭素棒を用い た場合には，無担持や白金担持炭素棒を用いた場合に比較し $\tau, \mathrm{C}_{3}$ 炭化水素の選択率が高く, さらにロジウム担持の場合 のみ $\mathrm{C}_{4}$ 炭化水素の生成が認められる。

\section{謝辞}

白金族元素の触媒作用についてご教唆賜りました日本大学文 理学部教授の高木弦先生に感謝の意を表します。

\section{References}

1) Broutin, P., Busson, C., Weill, J., "Novel Production Methods for Ethylene, Light Hydrocarbons, and Aromatics," eds. by Albright, L.F., Crynes, B.L., Nowak, S., Marcel Dekker Inc., New York (1992), p. 239.

2) Mochida, I., Aoyagi, Y., Yatsunami, S., Fujitsu, H., J. Analytical and Applied Pyrolysis, 21, 95 (1991).

3) Yamaguchi, T., Kadota, A., Saito, C., Chem. Lett., 681 (1988).

4) Yamaguchi, T., Cui, X., Tansoshigen no kagakutekiriyou ni kansuru kenkyuuhappyou kouennkai youshishu, Koubunshi Gakkai, 1991, p. 1 .

5) Belgued, M., Pareja, P., Amarigio, A., Amarigio, H., $\mathrm{Na}$ ture, 352, 789 (1991)

6) Solymosi, F., Erdohelyi, A., Cserenyi, J., Catal. Lett., 16, 399 (1992).

7) Yu, Z., Choi, K., Rosynek, M.P., Lunsford, J.H., React. Kinet. Catal. Lett., 51, (1), 143 (1993). 


\title{
Summary
}

\section{Dehydrogenative Coupling of Methane in the Thermal Diffusion Reactor with Platinum Metal Group Supported on a Carbon Rod as a Pyrogen}

\author{
Shin-Ichi Suzuki ${ }^{\dagger 1)}$, Jun Tamura ${ }^{\dagger 2)}$, Shuichi Ohara ${ }^{\dagger 2)}$, Kaoru OnoE ${ }^{\dagger 2)}$, \\ and Tatsuaki YamaguCHI ${ }^{\dagger 2}$ \\ 11) Technology Research Center, Japan National Oil Corporation, \\ 1-2-2 Hamada, Mihama-ku, Chiba 261 \\ 12) Dept. of Industrial Chemistry, Chiba Institute of Technology, 2-17-1 \\ Tsudanuma, Narashino, Chiba 275
}

Using the thermal diffusion reactor, which was known to depress successive reactions of products, the effects of modification of pyrogen surface on dehydrogenative coupling of methane were studied. The platinum metal group (platinum, ruthenium, rhodium), which is well known to promote hydrogenparticipating reaction, was supported on a carbon, as a surface-modified pyrogen. In the experiment, methane was downwardly fed into the Clusius-Dickel type thermal diffusion reactor (inner tube: I.D. $14.5 \mathrm{~mm}$, L $300 \mathrm{~mm}$, outer tube: I.D. $32.0 \mathrm{~mm}$, L $250 \mathrm{~mm}$ ) with $1.64 \mathrm{mmol} \cdot \mathrm{min}^{-1}$; the temperature of pyrogen was set at
$800-1300 \mathrm{~K}$, in which little amount of tar or carbon was produced. Concerning the results, it was observed that the rate of dehydrogenative coupling of methane and gaseous hydrocarbon yield were increased by using the platinum metal group supported on the carbon rod, compared to the absence of the platinum metal group. It should be attributed to the combined effects of the promotion of the dehydrogenation rate of methane by the platinum metal group and the separation of firstformed gaseous hydrocarbons from the reaction zone by thermal diffusion.

\section{Keywords}

Dehydrogenation, Supported catalyst, Methane, Thermal diffusion reactor, Platinum metal group,

Carbon rod pyrogen 